Max-Planck-Institut für demografische Forschung

Max Planck Institute for Demographic Research

Konrad-Zuse-Strasse 1 - D-18057 Rostock = Germany = Tel +49 (0) 3812081 - 0 - Fax +49 (0) 3812081 - 202 - www.demogr.mpg.de

MPIDR Working Paper WP 2020-002 I January 2020

https://doi.org/10.4054/MPIDR-WP-2020-002

\title{
Living arrangements across households in Europe
}

Chia Liu I liu@demogr.mpg.de

Albert Esteve

This working paper has been approved for release by: Peter Eibich (eibich@demogr.mpg.de),

Deputy Head of the Research Group: Labor Demography.

(ㄷ) Copyright is held by the authors.

Working papers of the Max Planck Institute for Demographic Research receive only limited review. Views or opinions expressed in working papers are attributable to the authors and do not necessarily reflect those of the Institute. 


\title{
Living arrangements across households in Europe \\ Chia Liu and Albert Esteve
}

\begin{abstract}
This chapter examines family living arrangements across 21 European countries. We focus on coresidence among nuclear family members and lone living. We use Eurostat's Labour Force Survey (EULFS) data to examine regional variations in living arrangements by age and sex and changes between 2006 and 2016. We focus on three main aspects of living arrangements: parental coresidence among young adults in their late twenties; dual or single parent households; and lone living at different stages of life. Despite European commonalities compared to other regions of the worlds, significant variations remain within Europe, mostly shaped by life events surrounding the transition to adulthood. Northern and Western Europeans show earlier transition to adulthood, and higher prevalence of single-person households. Southern and Eastern Europeans are marked by higher propensity to live with parents until older ages, with Southern Europeans characterized by late union formation and childbearing.
\end{abstract}

Keywords adulthood, coresidence, Europe, EU-LFS, family, living arrangements

\section{Introduction}

This chapter explores the living arrangements within households across 21 European countries. Globally, European living arrangements are characterized by uniquely high levels of single-person households, predominance of nuclear families and low levels of intergenerational coresidence between adult children and their parents (Eurostat, 2015; United Nations, 2018). Compared to other regions of the world, European households show lower levels of complexity compared to Africa, Latin America or Asia (Esteve et al., 2012; Esteve \& Liu, 2018). The presence of kin in European households overwhelmingly consists of married or cohabiting parents with their minor children. However, despite similarities, living arrangements between European countries are far from homogenous. A high level of heterogeneity of family forms and household types can be found across sub-regions and countries within Europe.

The diversity of living arrangement in Europe is a result of deep historical roots of family systems that trace back to preindustrial times (Hajnal, 1982). Debates over the structural or cultural nature of this diversity have been present since the late nineteenth century. The main focus of attention was on intergenerational coresidence between adult children and their parents. Earlier scholarship on intergenerational coresidence centered on its relationship with economic development (le Play, 1871). By the twentieth century, it was widely accepted that single-generation nuclear families had become dominant in the West as a response to the needs for flexible and individualized individuals of industrial societies(Burgess, 1916; Ogburn, 1933; Parsons, 1949). With economic development, the nuclear family would inevitably spread across the world (Goode 1963). However, little, if any, of this theorizing was informed by empirical analyses of large-scale trends until Peter Laslett compiled crude measures of family composition for 100 preindustrial English communities (Laslett \& Wall, 1972). His findings led to the revisionist hypothesis that there was no long-term change in family composition (Hareven, 1993) and that the indelibility of family norms and values would ensure regional diversity for centuries to come (Hajnal, 1965; Reher, 1998; Thornton, 2013). This vision is proven true by regional diversity in living arrangements still present in Europe.

This chapter provides an account of Europe's regional diversity in living arrangements. A traditional way to approach the study of family diversity is by using the family as a unit of analysis. Given the nature of our data, we take an "individual approach" in which we use the individual as a unit of analysis and classify the respondents by their living arrangement. By doing so, we can break down the analysis by individual-level characteristics, such as by age and sex. The age distribution of living arrangements provide valuable information for characterizing family diversity over the life-course and across countries. A tabulation of living arrangements by age furthermore gives insights into when people experience major transitions in the family domain for their life courses, such as leaving parental homes, partnership formation, having children, and union dissolution. This chapter highlights the diversity within contemporary Europe and allow us to investigate at which ages Europeans are more likely to diverge and to share similarities in living arrangements. Data for this analysis comes from the Labour Force Survey 2006 and 2016. 


\section{$2 \quad$ Family transitions and family diversity}

Based on previous literature and knowledge of family dynamics in Europe (Buchmann \& Kriesi, 2011), we expect that cross-national variations in key transitions to adulthood (Billari \& Wilson, 2001; Goldscheider \& DaVanzo, 1985) will have the largest implications for living arrangements. These transitions center around the magnitude and timing of leaving the parental home, forming a union and having children. The first transition determines the length of coresidence with parents. Coresidence with parents (or at least one parent) is universal for young children in Europe until departure from the parental home, which typical occurs after they reach adulthood. This takes place at different ages across European countries. It occurs later for the young adults in Mediterranean countries, compared to those in Northern or Western Europe (Reher, 1998). Moving out of the parents' household may coincide with the timing of conjugal union formation (Billari \& Liefbroer, 2010; Fokkema \& Liefbroer, 2008) in a substantial number of cases. However, the widespread postponement of union formation weakens this association. The postponement of union formation has direct implications for living arrangements. The young adults may set up their own independent household or extend their coresidence with their parents before entering into a committed relationship.

Regardless of differences in age at union formation and in union type, married or cohabiting couples live independently from their parents. Multigenerational households in Europe are generally uncommon. Most Europeans do not simultaneously live with their parents, spouse and children at the same time. Women tend to depart from their parents' home earlier than men because women form conjugal unions at younger ages than men (Eurostat, 2019). Unlike in other parts of the world, such as in Asia (Esteve \& Liu, 2018), stem-family in the form of intergenerational coresidence of married adult children with their parents is far less common in Europe.

Marriage or partnership formation usually marks the end of parental coresidence, and the beginning of coresidence with a partner, and usually children. Despite the drop in fertility rate across European countries and an increase in childlessness, especially for the highly educated women, complete and voluntary childlessness among couples is still rare in Europe (Miettinen et al., 2015). Most middle-aged, partnered individuals therefore also live with at least one minor child. However, due to higher rates in union dissolution single parenthood has been rapidly increasing in Europe. This has direct implications for living arrangements as it decreases coresidence between the spouses and reduces the percent of children raised by both parents in the same household.

Finally, living alone is also a non-negligible type of living arrangement in the European context. The percent of people living alone differs greatly by age and sex. The propensity of an individual to forego union formation, to exit dysfunctional relationships, and to remain single after union dissolution or widowhood, hence live alone in old age, are more common in Europe than in the rest of the world (Esteve et al., forthcoming; United Nations, 2018), in particular, among elderly women. At younger ages, postponement of union formation and childbearing may contribute to increasing levels of people living alone together with union dissolution and childlessness.

\section{Data and Methods}

Using data from the cross-sectional European Labor Force Survey (EU-LFS), we examine the living arrangements of Europeans across different life stages, and describe changes between the years 2006 and 2016 by country, sex, and age. The EU-LFS is a collection of nationally representative random sample surveys across 35 European countries. Access to the data is provided through EUROSTAT through quarterly and yearly files. The data has been harmonized to facilitate cross-national comparisons (e.g. Alders \& Manting, 2001; Fokkema \& Liefbroer, 2008). For this chapter, we use yearly files and select two data points: 2006 and 2016. The study of living arrangements requires microdata in which households and family units can be identified. The analysis is therefore restricted to those samples including household level data. Most Scandinavian countries are excluded from our analyses due to the unavailability of household information for these countries from the EU-LFS, rendering our final analyses to 21 countries. For presentation purposes, we classify them in for sub-regions based on a geographic criteria: Southern Europe, Eastern Europe, Northern Europe, Western Europe.

EU-LFS samples provide key information required to establish who is related with whom within the household. In particular, it links children with parents, parents with children, and conjugal partners with each other (either married or cohabiting). Therefore, for every person, we know whether his or her parents, partner or children are present in the household. We focus exclusively on three partially overlapping categories in this chapter, namely (1) presence of partner in the household, (2) presence of children in the household, (3) presence of parents in the household and (4) living alone. Since coresidence of adult respondents with own grandparents or other relatives is rather uncommon across European households, we do not take into account further categories and living arrangements. We focus on analyses on respondents aged 0-79. Those aged 80 and above are omitted as the risk of entering intuitional care increases rapidly with age and the data is not suited for investigating non-private households. 


\section{The structure of living arrangements across European countries}

\subsection{Patterns by age}

Figure 1 shows the aggregate pattern of coresidence by age on data from 21 European countries. Each panel of the boxplots depicts the percentage of men and women living with parents, spouse, children or alone by age. The categories are not mutually exclusive. This figure displays the general age pattern of living arrangements and variations across countries. Box plots depict groups of numerical data through their quartiles. The band inside the box indicates the second quartile (the median), and the bottom and top limit indicate the lower and upper quartile respectively. The upper and lower whiskers represent values outside of the upper and lower quartiles. The length of the boxes shows the extent of variation across European countries.

The living arrangements for children in Europe are remarkably similar before age 20. The vast majority of children in these ages live with at least one parent. If the child lives with only one parent (results not shown here), it is with the mother in over 90 per cent of the cases. As individuals reach their early twenties, coresidence with parents rapidly declines, while spousal and child coresidence rises around the mid-twenties to thirties. Propensity to live alone is generally low throughout the earlier stages of the life course, but increases with age. However, gender differences are clear. First, women tend to leave parental home earlier than men. This strongly coincides with the timing of union formation, which generally happens at younger ages for women than for men. At age 25, about 75 per cent of men live with parents, whereas roughly 70 per cent for women do so. For 30 year olds, that gap widens to roughly 51 per cent versus 30 per cent. Second, men have stable spousal coresidence throughout the life course, with high spousal coresidence ( 75 per cent) from ages 40 onward until close to 80 years of age, whereas women experience similar level of coresidence as men around 40 years of age, but see a drop after 50 . Women's coresidence with children is higher in the peak years for child coresidence, namely 30 to 50 years old, compared to their male counterparts. In the older age groups, women are more likely to live alone, with over 50 per cent of women living alone past age 85 , and the figure is roughly 10 percentage points lower for men of the same age group. This is mainly due to the tendency for men to partner with younger women hence are less likely to experience widowhood than women, who are usually partnered with older men. Living with one's child in old age is not the general norm in Europe, with only about one quarter of older individuals living with a child.

These general age patterns and gender differences hold across all European countries, but within-region variations remain. Such variations are directly attributed to differences in the timing and intensity of leaving the parental home, union formation, childbearing, union dissolution, and widowhood. The largest cross-national differences are observed between ages 20 and 34 and is mostly determined by the different tendency to live with parents. At ages 25-29 we find the largest differences in parental coresidence across Europe for both men and women. In the case of men, differences in parental coresidence range between values below 20 per cent and values above 90 per cent. Cross-national variations in partner and children coresidence among young adults are substantial as well but not to the level observed in parental coresidence. Variations in parental coresidence are, to a certain extent, replicated at older ages when we observe the prevalence of parent-child coresidence from the parents' perspectives. From that perspective, cross-national differences are lower because not all persons have children and those who became parents did so at different ages. However, even after taking these factors into account, coresidence with children at the ages 55-59 ranges from less than 25 per cent and 75 per cent. By contrast, the living arrangements among Europeans between the late thirties and the forties are similar. 
Figure 1: Percentage of individuals living with parent(s), spouse/partner, child(ren), or alone by age and sex in 21 European countries in 2016

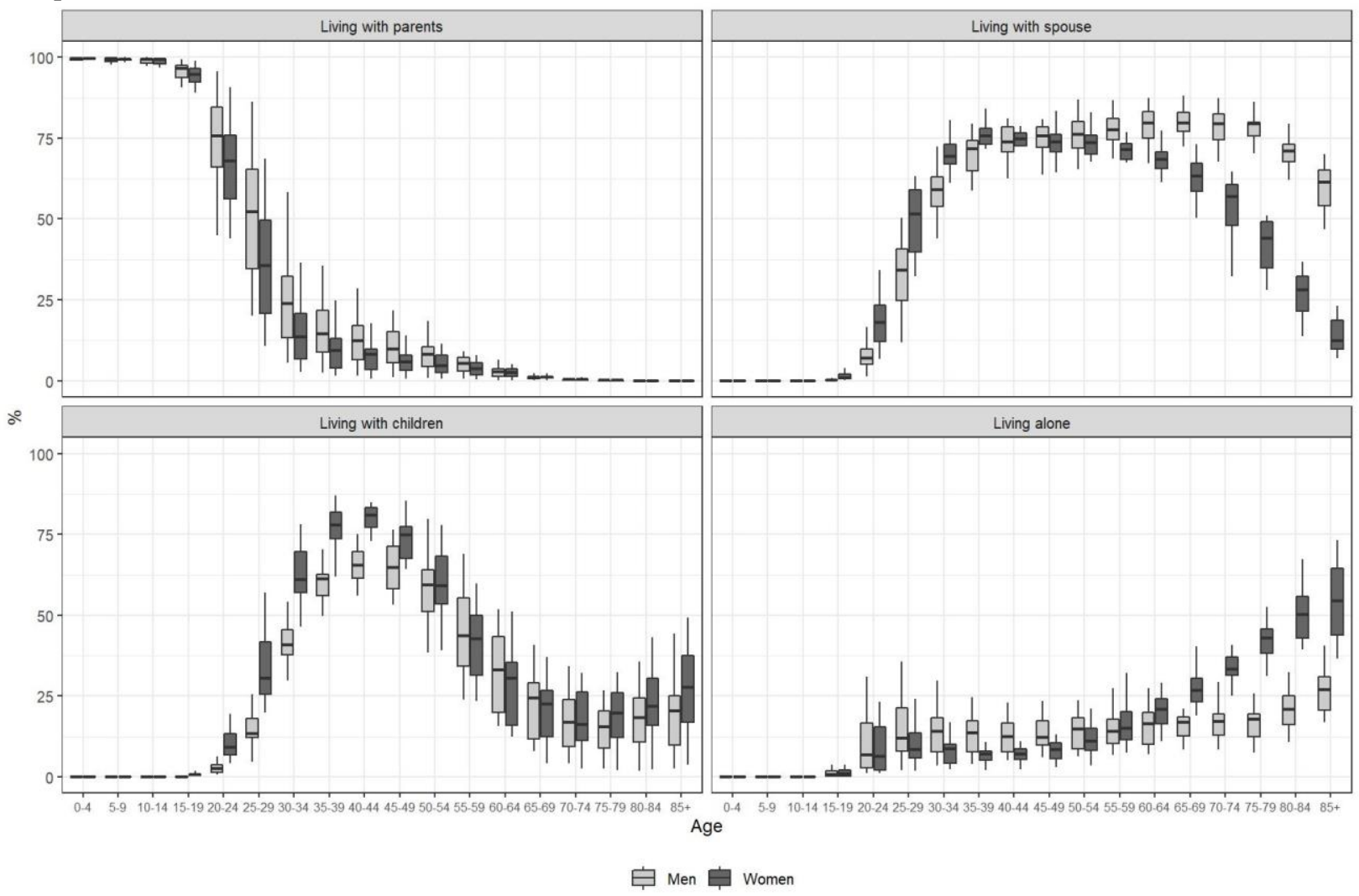

Source: EU-LFS 2016, authors’ elaboration

Next, we examine changes of living arrangements across Europe between 2006 and 2016 in Figure 2. The four panels show the absolute change in the percentage of individuals living with parents, spouse, children, and alone by age and sex between the two years. Living arrangements is far from static during the observed period. In contrary, substantial changes are observed in all types of coresidence. Some of these changes are occurring simultaneously in all countries, whereas in others trends are diverging.

Parental coresidence has remained stable for the majority of age groups but shows a widespread increase in the late twenties. In the majority of countries, 25-29 years olds were more likely to coreside with parents in 2016 than in 2006, suggesting a delay in leaving the parental home. Conversely, spousal coresidence showed a visible decrease throughout adulthood, and a sizable increase in the late adulthood. These trends are likely to be the combination of multiple factors, including increases in singlehood, delay in marriage or cohabitation and union dissolution. However, the late life increase in spousal coresidence is likely attributable to longer life expectancy, where both sexes are less likely to experience widowhood, with women showing a higher increase. In line with lower spousal coresidence, child coresidence has declined across all adult age groups between 2006 and 2016. For the oldest age groups, little changes have been observed in child coresidence. Individuals roughly aged 35 to 50, saw a 2-3 per cent increase in living alone, while the oldest individuals are less likely to live alone, which corresponds with higher spousal coresidence in the plot above, due to the fact that increases in life expectancy are also increasing the duration of couples (assuming that they do not divorce or separate). 
Figure 2 : Percentage change of living arrangements by age, sex, and type of coresidence for 21 European countries from

to

2016

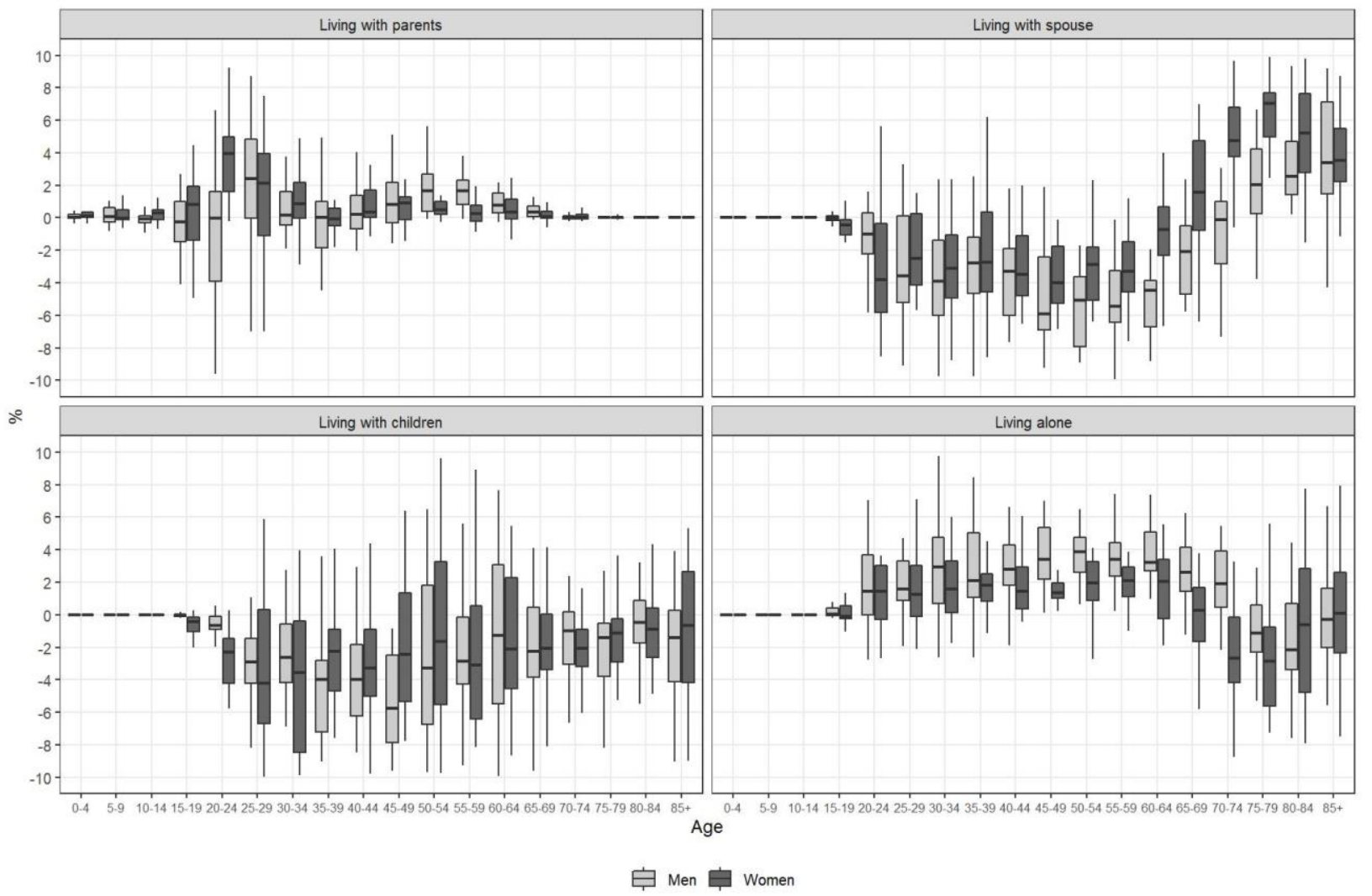

Source: EU-LFS 2006 and 2016, authors' elaboration

\subsection{Coresidence with parents}

Bearing the patterns observed in Figures 1 and 2, we now turn our attention to those ages and types of coresidence in which we see the largest cross-national variations. We start by examining coresidence with parents among 25-29 years old men and women. In Table 1, we show the percentage of individuals living with at least one parent between the ages of 25 and 29 by sex, union status and country. We distinguish the following overlapping categories a) single meaning that the person does not live with a partner in the same household, b) living with a partner, regardless of the person is married or not c) not in union but widowed, divorced or legally separated. In the first column, we show the total percentage of parental coresidence of young men as depicted in Figure 1. By regions, Eastern and Southern European countries show the highest levels of coresidence, compared to lower levels in Northern and Western Europe. By country, Hungary (86.2), Italy (74.3), and Greece (73) showed the highest level of parental coresidence. The lowest percentages are seen for young adults in Estonia (20.2) and the Netherlands (2.8). Parental coresidence for young women are lower than men's across board, with Hungarian women the highest (68.7) and Dutch women the lowest (10.6).

The percentages of singles living with parents is close to the total as the vast majority of persons living with parents at these ages are single. Again, Southern and Eastern European countries show the highest values and the Western and Northern European ones the lowest. Hungarian (94.6), Slovakian (84.5), and Italian (80.6) single men are particularly likely to live with at least one parent. Estonian single men, on the other hand, are far less likely to live with parents, at 23.5 per cent. Single women in Hungary (95), Slovakia (76.1), Italy (75.5) and Greece(74.7) show high parental coresidence. Despite gender differences in the level of coresidence, the countries generally show indiscriminate propensity in parent-adult daughter or parent-adult son coresidence.

Married or partnered individuals tend to not live with parents, as patrilocality or matrilocality are uncommon in Europe. Despite these lower levels, there are substantial differences across regions and countries. Eastern Europe show the highest levels of coresidence among married/in union populations, with values above 15 per cent for men 
except in Czech Republic. Hungary and Romania show high intergenerational coresidence for married young men, at over one third of married sons living with their parents. About one out of every six young, married women from Poland, Cyprus and Hungary have similar living arrangements. There are no systematic differences between men and women, suggesting no clear evidence for patrilocality versus matrilocality, although a sounder conclusion about this would require further analysis.

The individuals who were not in union but were widowed, divorced or legally separated are more likely than those in union, but less likely than their single counterparts, to live with their parents. Systematically, men in this situation are more likely to coreside with parents than women. Southern and Eastern European countries show the highest levels and the largest difference with respect to the married or in union population.

Table 1: Percentage 25-29 year olds living with at least one parent by sex, marital status and country in 2016

\begin{tabular}{|c|c|c|c|c|c|c|c|c|}
\hline \multirow[b]{3}{*}{ Country } & \multicolumn{4}{|c|}{ Males } & \multicolumn{4}{|c|}{ Females } \\
\hline & Total & Single & $\begin{array}{c}\text { In } \\
\text { union }\end{array}$ & $\begin{array}{l}\text { Widowed, } \\
\text { divorced, legally } \\
\text { separated }\end{array}$ & Total & Single & $\begin{array}{l}\text { In } \\
\text { union }\end{array}$ & $\begin{array}{l}\text { Widowed, } \\
\text { divorced, legally } \\
\text { separated }\end{array}$ \\
\hline & & & & & & & & \\
\hline \multicolumn{9}{|l|}{ Western Europe } \\
\hline Austria & 34.7 & 38.7 & 16.2 & 29.1 & 20.7 & 27.4 & 4.3 & 19.7 \\
\hline Belgium & 36.9 & 41.0 & 7.2 & 26.3 & 21.9 & 28.1 & 3.5 & 14.3 \\
\hline France & 24.4 & 27.5 & 3.6 & 37.3 & 12.4 & 15.1 & 2.4 & 10.7 \\
\hline Germany & 23.2 & 27.7 & - & - & 13.1 & 18.7 & - & - \\
\hline Netherlands & 21.8 & 25.8 & 1.0 & - & 10.6 & 14.1 & 1.7 & - \\
\hline \multicolumn{9}{|l|}{ Northern Europe } \\
\hline Estonia & 20.2 & 23.5 & 3.0 & 19.2 & 14.6 & 19.1 & 2.5 & 23.9 \\
\hline Ireland & 45.0 & 49.3 & 7.6 & 9.0 & 36.6 & 44.1 & 4.4 & 22.0 \\
\hline Latvia & 52.2 & 63.1 & 10.2 & 7.7 & 35.6 & 48.3 & 12.6 & 34.6 \\
\hline Lithuania & 38.4 & 47.5 & 13.4 & 34.1 & 21.8 & 37.5 & 7.8 & 11.8 \\
\hline United Kingdom & 29.9 & 36.1 & 6.4 & 16.4 & 17.3 & 24.5 & 1.8 & 6.0 \\
\hline \multicolumn{9}{|l|}{ Eastern Europe } \\
\hline Czech Republic & 44.7 & 52.0 & 2.7 & 18.8 & 25.6 & 34.6 & 4.3 & 14.7 \\
\hline Hungary & 86.2 & 94.6 & 47.6 & - & 68.7 & 95.0 & 15.1 & - \\
\hline Poland & 53.7 & 72.6 & 15.8 & 56.5 & 38.8 & 63.2 & 16.2 & 51.8 \\
\hline Romania & 64.8 & 74.9 & 35.2 & 56.1 & 33.2 & 61.8 & 9.0 & 56.5 \\
\hline Slovakia & 75.1 & 84.5 & 25.3 & 13.3 & 58.0 & 76.1 & 21.5 & 49.2 \\
\hline \multicolumn{9}{|l|}{ Southern Europe } \\
\hline Cyprus & 53.0 & 64.2 & 12.4 & 58.8 & 45.6 & 62.9 & 15.8 & 28.4 \\
\hline Greece & 73.0 & 78.5 & 15.1 & 70.3 & 54.9 & 74.7 & 6.0 & 67.6 \\
\hline Italy & 74.3 & 80.6 & 13.6 & 31.3 & 58.1 & 75.5 & 4.6 & 41.9 \\
\hline Portugal & 65.3 & 70.8 & 9.3 & 56.4 & 51.9 & 61.1 & 13.4 & 12.7 \\
\hline Slovenia & 58.3 & 62.5 & 18.5 & - & 44.2 & 55.7 & 5.0 & 41.2 \\
\hline Spain & 67.8 & 73.2 & 6.4 & 49.6 & 49.6 & 60.0 & 6.8 & 41.2 \\
\hline
\end{tabular}

Source: EU-LFS 2016, authors' elaboration. Empty cells indicate lack of cases in this category. 


\subsection{Spousal and child coresidence at different life stages}

Next, we look at spousal and child coresidence for individuals in the age groups of 25 to 29,40 to 44 , and 55 to 59 based on 2016 data. The left part of Table 2 shows the percentage of individuals by sex and age group living with a (married or unmarried) partner. The right part displays the percentage of all individuals who live with children out of all persons in a union. Results by country show that in France over half of men and about 63 per cent of women are married or partnered by the ages 25 to 29 . The figures are similar for the Netherlands, the United Kingdom, and Estonia, but far lower in the Southern European countries. Less than 12 per cent of men in Greece and about 13 per cent of men in Italy of the same age group have formed conjugal union.

Out of all those who are in a union at ages 25 to 29, the percentage having children is higher in the Baltic states and in Eastern European countries. About 71 per cent of men and three quarters of partnered women have children in Latvia, compared to less than one quarter men and 36.4 per cent of women in the Netherlands. Within each geographic region, France, Latvia, Hungary, and Italy are particularly marked by earlier childbearing than their neighbours.

By ages 40 to 44, the proportion of individuals in a union reaches its peak. Compared to the age group 25 to 29 , by 40 to 44 , gender differences in spousal and child coresidence diminish, with men actually showing a higher level of spousal coresidence in some countries. However, depending on partnership formation, union dissolution and repartnership patterns, spousal coresidential patterns can be difficult to disentangle. Spousal coresidence for men is over 80 per cent in Poland, Romania, and Cyprus, and over 70 per cent in most countries. For women in countries other than the Baltic states, spousal coresidence is over 70 per cent in all countries, and close to 85 per cent in Romania. Most coupled individuals in the 40 to 44 age group have children.

The oldest age group in Table 2, 55 to 59 year olds, shows the percentage of men and women living with own children. Parent-child coresidence for this age group can be due to two different contexts: children have not reached adulthood, or children have reached adulthood but continued to remain in their parental household. Considering the average age of childbearing in 1985 is roughly 26 years old for women in today's EU-25 (Eurostat, 2006), and most individuals partner with those close to their age, we can assume that on average 55-59 year old parents in 2016 most likely have children in the age range of 25 to 35 . However, men are more likely to have younger children on the aggregate, particular those who partnered or re-partnered with much younger women. As previously described for Figure 1, the large cross-national differences regarding coresidence with children at these ages are likely to reflect differences in age patterns of leaving parental homes among young adults. Northern and Western European countries show lower levels of coresidence compared to the levels of observed in Eastern and Southern Europe. Women show systematically lower levels of coresidence mainly due to early patterns of childbearing. 
Table2: Percentage of individuals living in union (spouse or partner) and percentage in union living with children by sex, selected age groups, and country in 2016

\begin{tabular}{|c|c|c|c|c|c|c|c|c|c|c|c|c|}
\hline & \multicolumn{6}{|c|}{$\%$ living in union } & \multicolumn{6}{|c|}{ Only respondent in union: \% living with children } \\
\hline & \multicolumn{3}{|c|}{ Males } & \multicolumn{3}{|c|}{ Females } & \multicolumn{3}{|c|}{ Males } & \multicolumn{3}{|c|}{ Females } \\
\hline & $25-29$ & $40-44$ & $55-59$ & $25-29$ & $40-44$ & $55-59$ & $25-29$ & $40-44$ & $55-59$ & $25-29$ & $40-44$ & $55-59$ \\
\hline \multicolumn{13}{|l|}{ Western Europe } \\
\hline Austria & 36.3 & 70.5 & 74.6 & 52.5 & 75.6 & 67.5 & 39.5 & 86.5 & 49.7 & 49.3 & 87.1 & 38.3 \\
\hline Belgium & 39.4 & 73.9 & 72.1 & 57.8 & 72.7 & 68.2 & 32.9 & 78.3 & 44.0 & 33.6 & 74.7 & 28.8 \\
\hline France & 50.4 & 74.9 & 76.3 & 62.9 & 73.8 & 68.4 & 41.2 & 86.0 & 40.0 & 52.3 & 90.1 & 29.4 \\
\hline Germany & 34.1 & 67.9 & 73.1 & 51.5 & 72.7 & 71.8 & 34.4 & 79.2 & 38.4 & 43.4 & 82.2 & 27.3 \\
\hline Netherlands & 43.9 & 74.4 & 75.3 & 59.5 & 76.4 & 75.8 & 23.9 & 85.5 & 47.9 & 36.4 & 85.2 & 33.8 \\
\hline \multicolumn{13}{|l|}{ Northern Europe } \\
\hline Estonia & 43.5 & 72.8 & 68.6 & 63.4 & 66.2 & 53.9 & 58.0 & 81.3 & 32.9 & 71.5 & 88.5 & 25.8 \\
\hline Ireland & 28.4 & 79.0 & 77.7 & 39.8 & 74.1 & 71.4 & 42.3 & 87.6 & 63.1 & 53.2 & 90.5 & 54.2 \\
\hline Latvia & 37.3 & 64.6 & 70.3 & 52.5 & 64.5 & 55.2 & 70.5 & 85.7 & 47.1 & 75.4 & 86.0 & 43.6 \\
\hline Lithuania & 25.6 & 62.6 & 63.8 & 42.2 & 57.8 & 51.0 & 58.8 & 92.1 & 39.0 & 74.5 & 89.5 & 32.0 \\
\hline United Kingdom & 50.3 & 79.3 & 77.3 & 59.7 & 72.8 & 70.0 & 41.3 & 79.9 & 41.3 & 48.9 & 83.7 & 33.4 \\
\hline \multicolumn{13}{|l|}{ Eastern Europe } \\
\hline Czech Republic & 41.2 & 77.1 & 81.1 & 59.1 & 75.3 & 71.2 & 43.0 & 86.6 & 38.6 & 54.1 & 89.0 & 25.9 \\
\hline Hungary & 17.9 & 74.4 & 82.3 & 32.2 & 78.6 & 76.2 & 66.9 & 91.7 & 75.2 & 72.4 & 95.5 & 61.0 \\
\hline Poland & 40.8 & 81.1 & 80.9 & 56.9 & 78.3 & 73.4 & 59.5 & 91.3 & 51.0 & 67.6 & 90.8 & 43.4 \\
\hline Romania & 32.6 & 80.9 & 78.9 & 61.0 & 84.9 & 71.1 & 53.7 & 88.7 & 58.4 & 64.5 & 88.2 & 47.1 \\
\hline Slovakia & 21.5 & 72.5 & 82.3 & 41.2 & 76.6 & 70.3 & 67.8 & 92.2 & 59.3 & 70.0 & 92.7 & 49.4 \\
\hline \multicolumn{13}{|l|}{ Southern Europe } \\
\hline Cyprus & 34.2 & 80.5 & 86.7 & 45.2 & 72.5 & 74.4 & 37.9 & 90.3 & 76.3 & 50.6 & 92.5 & 61.4 \\
\hline Greece & 11.7 & 71.8 & 84.2 & 33.9 & 78.3 & 76.9 & 38.9 & 81.5 & 63.3 & 56.2 & 83.6 & 46.7 \\
\hline Italy & 13.2 & 70.7 & 79.7 & 32.9 & 74.8 & 72.7 & 57.0 & 84.5 & 77.4 & 65.8 & 87.2 & 66.3 \\
\hline Portugal & 26.3 & 78.6 & 82.7 & 37.6 & 73.5 & 75.5 & 45.3 & 91.5 & 66.4 & 51.2 & 93.1 & 55.8 \\
\hline Slovenia & 24.7 & 70.7 & 75.4 & 43.7 & 78.6 & 72.5 & 51.7 & 89.6 & 58.6 & 62.4 & 91.4 & 45.9 \\
\hline Spain & 22.1 & 73.0 & 78.8 & 39.8 & 74.8 & 72.5 & 40.6 & 82.7 & 70.2 & 47.1 & 86.1 & 60.6 \\
\hline
\end{tabular}

Source: EU-LFS 2016, authors' elaboration 


\subsection{Single parenthood}

The patterns of living arrangements described up to this point are observed through a set of non-mutually exclusive categories. Therefore, in theory and practice, one person can live with parents, spouse and children at the same time. Of all possible combinations, we focus on single parenthood, which in our case applies to all persons coresiding with at least one child but not with a spouse. In the majority of cases, this is likely the results of union dissolution, but we cannot verify this, given the limitations of the data. Results are shown in Table 3, which indicates the prevalence of single parenthood in Europe by sex, age group, and country. Single parenthood is far lower for men than women at any age and anywhere. It is more common in Northern Europe, and peaks around 40 years of age.

In the age group 25-29, very few men in Europe live with a child but without a partner, with only Latvia and Lithuania the highest, hovering around one per cent. For women, the figure ranges from one per cent in Greece to 14.7 per cent in Latvia in the same age group, with other Northern European countries in the same ballpark. Outside of Northern Europe, France, Czech Republic, Poland, and Slovakia also show higher proportion of young single mothers, at over eight per cent each. By age 40-44, the percentage of unpartnered men and women with children double or triples for most countries. Lithuania leads European countries with over 30 per cent of women and over six per cent of men living with at least one child without a partner. Women in Greece and men in Italy are the least likely to be single parents, at eight per cent and less than one per cent respectively. In late adulthood, 55 to 59 , living with children without a partner slightly increases for men in some countries, especially in Southern Europe and Belgium. This figure generally declines for women, except for women in Romania, Hungary, Greece, Italy, Spain, and Slovenia. This difference is likely due to having children at later ages for men. 
Table 3: Percentage living with child(ren) but without a partner by sex, selected age groups, and country in 2016

\begin{tabular}{|c|c|c|c|c|c|c|}
\hline & \multicolumn{3}{|c|}{ Males } & \multicolumn{3}{|c|}{ Females } \\
\hline & $25-29$ & $40-44$ & $55-59$ & $25-29$ & $40-44$ & $55-59$ \\
\hline \multicolumn{7}{|l|}{ Western Europe } \\
\hline Austria & 0.1 & 1.2 & 2.4 & 4.1 & 11.3 & 7.8 \\
\hline Belgium & 0.5 & 2.4 & 5.3 & 4.2 & 13.3 & 10.3 \\
\hline France & 0.6 & 4.2 & 3.5 & 8.5 & 17.0 & 9.1 \\
\hline Germany & 0.5 & 2.2 & 2.3 & 5.9 & 13.2 & 5.4 \\
\hline Netherlands & 0.2 & 1.8 & 3.3 & 3.9 & 12.2 & 5.7 \\
\hline \multicolumn{7}{|l|}{ Northern Europe } \\
\hline Estonia & 0.3 & 3.1 & 1.3 & 11.6 & 21.5 & 9.5 \\
\hline Ireland & 0.2 & 1.2 & 2.7 & 12.2 & 15.3 & 11.3 \\
\hline Latvia & 1.2 & 3.2 & 4.5 & 13.3 & 24.4 & 18.4 \\
\hline Lithuania & 1.0 & 6.2 & 4.1 & 14.7 & 30.3 & 15.3 \\
\hline United Kingdom & 0.3 & 2.0 & 2.4 & 12.6 & 16.6 & 9.6 \\
\hline \multicolumn{7}{|l|}{ Eastern Europe } \\
\hline Czech Republic & 0.3 & 2.1 & 2.0 & 8.2 & 16.1 & 8.8 \\
\hline Hungary & 0.3 & 1.5 & 3.3 & 2.1 & 8.4 & 13.3 \\
\hline Poland & 0.3 & 1.1 & 2.3 & 8.9 & 13.6 & 10.7 \\
\hline Romania & 0.3 & 3.1 & 4.4 & 3.6 & 8.5 & 13.4 \\
\hline Slovakia & 0.3 & 1.9 & 2.3 & 8.3 & 14.0 & 13.5 \\
\hline \multicolumn{7}{|l|}{ Southern Europe } \\
\hline Cyprus & 0.2 & 2.2 & 2.9 & 3.7 & 14.6 & 10.9 \\
\hline Greece & 0.0 & 1.1 & 2.1 & 1.0 & 8.0 & 8.7 \\
\hline Italy & 0.3 & 0.9 & 2.8 & 2.9 & 9.6 & 10.9 \\
\hline Portugal & 0.1 & 2.2 & 3.3 & 6.3 & 15.0 & 11.6 \\
\hline Slovenia & 0.5 & 2.0 & 2.2 & 3.2 & 9.1 & 9.7 \\
\hline Spain & 0.6 & 1.1 & 3.4 & 5.0 & 11.0 & 12.9 \\
\hline
\end{tabular}

Source: EU-LFS 2016, authors' elaboration 


\subsection{Living alone}

Lastly, we show the percentage of those living alone by sex, age group, and country in Table 5. Living alone can occur in different life stages, but particularly in later life. We use the age groups 25 to 29,55 to 59 and 75 to 79 to capture different contexts of single living at various life stages.

For 25 to 29 years old individuals, living alone at this age entails that they have already left their parental home but have not (yet) set up their own conjugal household, which can be seen as transition to adulthood from the young adults' perspective. Living alone for the age group 55 to 59 can also reflect transition to adulthood, or the moving out of their young adult children, from the parents' perspective. It also approximates singlehood and union dissolution for those who have passed the peak of their union formation years. To account for singlehood specifically, we show the percentage of those who never married in parentheses. Lastly, the 75 to 79 years old individuals who live alone tend to be in the context of widowhood, or no longer living with children, rather than singlehood, since both childbearing and marriage were far more universal for this cohort, who were born between the years 1937 and 1941. We cap the age at 79 to avoid missing those who moved into nursing homes at very old ages, because EU-LFS does not systematically include individuals living in institutions.

Most European young adults living alone have not married by the ages 25 to 29, with most countries showing more than 95per cent of individuals unmarried, with the exceptions of Latvia and Lithuania. Therefore, parental coresidence is the most likely scenario for individuals of this age group. Young adults are far more likely to live alone in Western Europe than the rest of Europe. Almost 30per cent of German men and 23.1per cent of German women live alone between the ages 25 and 29. The Netherlands shows similar rate for men at 26.2 per cent and 23.5per cent for women. In other parts of Europe, the majority of young men and women do not live alone, with less than 1per cent of men living alone between the ages 25 to 29 in Estonia, Hungary, Cyprus, and Portugal up to 12.3per cent in Czech Republic and 12.1per cent in the United Kingdom. For women of the same age group, the figure ranges from lower than 5per cent for women in Ireland, Hungary, and Slovakia, to as high as 13.5 per cent in Estonia and 24.1per cent in Lithuania.

For the 55 to 59 year olds, Northern Europeans are generally more likely to live alone. This can both due to union instability in combination with childlessness or early departure of child(ren). More than one quarter of Lithuanian men in this age group live alone, compared to close to 30per cent of Lithuanian women. This living arrangement is far less common for Cypriot men and Hungarian men, at 6.7per cent and 8.5per cent respectively, and Hungarian women and Portuguese women, at 7.4per cent and 8.7per cent respectively. A larger proportion of men have never been married at this age compared to women of the same age group, whose single living might be more attributable to union dissolution, rather than singlehood.

In the oldest age group of our analyses, 75 to 79 , women are far more likely to live alone than men, and the percentage differences between the 55 to 59 age group and the 75 to 79 age group are starker for women. In most countries, men are similarly likely to live alone in the 55 to 59 and 75 to 79 age groups, whereas women's likelihood of single living more than doubles from one age group to the next in many countries. For example, about 20 per cent of 55 to 59 years old German men live alone, compared to roughly 20 per cent of 75 to 79 years old German men. For German women, only 17.7 per cent live alone in the 55-59 age group, but over half, or 52.5per cent of 75 to 79 year olds do so. Interestingly, Ireland has a remarkably high level of life-long male singlehood compared to other countries, with 42.4per cent of 75 to 79 years old men never married, whereas the figure is 16.3 per cent in the neighboring UK. 
Table 4. Percentage living alone and percentage never married among those living alone by sex, selected age groups, and country 2016

\begin{tabular}{|c|c|c|c|c|c|c|c|c|c|c|c|c|}
\hline & \multicolumn{6}{|c|}{$\%$ living alone } & \multicolumn{6}{|c|}{$\%$ never married among those living alone } \\
\hline & \multicolumn{3}{|c|}{ Males } & \multicolumn{3}{|c|}{ Females } & \multicolumn{3}{|c|}{ Males } & \multicolumn{3}{|c|}{ Females } \\
\hline & $\begin{array}{l}25- \\
29 \\
\end{array}$ & $\begin{array}{l}55- \\
59 \\
\end{array}$ & $\begin{array}{l}75- \\
79 \\
\end{array}$ & $\begin{array}{l}25- \\
29 \\
\end{array}$ & $\begin{array}{l}55- \\
59 \\
\end{array}$ & $\begin{array}{l}75- \\
79 \\
\end{array}$ & $\begin{array}{l}25- \\
29 \\
\end{array}$ & $\begin{array}{c}55- \\
59 \\
\end{array}$ & $\begin{array}{l}75- \\
79 \\
\end{array}$ & $\begin{array}{l}25- \\
29 \\
\end{array}$ & $\begin{array}{c}55- \\
59 \\
\end{array}$ & $\begin{array}{l}75- \\
79 \\
\end{array}$ \\
\hline \multicolumn{13}{|l|}{ Western Europe } \\
\hline Austria & 22.5 & 18.6 & 18.7 & 18.6 & 21.7 & 45.7 & 97.4 & 43.6 & 13.5 & 95.4 & 31.1 & 10.6 \\
\hline Belgium & 8.7 & 17.7 & 9.3 & 11.7 & 17.5 & 31.1 & 97.0 & 35.9 & 13.1 & 94.6 & 22.3 & 8.1 \\
\hline France & 12.6 & 17.4 & 18.5 & 14.6 & 20.7 & 43.9 & 98.6 & 49.4 & 15.7 & 99.8 & 31.0 & 9.0 \\
\hline Germany & 29.9 & 20.8 & 17.7 & 23.1 & 20.1 & 44.1 & 97.0 & 46.0 & 19.1 & 96.3 & 28.1 & 7.2 \\
\hline Netherlands & 26.2 & 19.9 & 20.1 & 23.5 & 17.7 & 52.5 & 98.9 & 46.1 & 22.2 & 99.0 & 40.4 & 6.2 \\
\hline \multicolumn{13}{|l|}{ Northern Europe } \\
\hline Estonia & 0.6 & 21.7 & 0.0 & 13.5 & 32.2 & 0.0 & 99.7 & 16.1 & 0.0 & 99.1 & 25.1 & 0.0 \\
\hline Ireland & 2.8 & 14.1 & 25.1 & 2.8 & 14.0 & 41.0 & 96.7 & 64.6 & 42.4 & 95.4 & 47.8 & 13.0 \\
\hline Latvia & 4.3 & 16.9 & 19.4 & 7.2 & 22.2 & 47.8 & 91.3 & 25.7 & 12.3 & 85.1 & 16.3 & 10.3 \\
\hline $\begin{array}{l}\text { Lithuania } \\
\text { United }\end{array}$ & 1.7 & 27.4 & 15.7 & 24.1 & 29.5 & 49.5 & 87.1 & 17.4 & 11.7 & 71.3 & 10.5 & 6.4 \\
\hline Kingdom & 12.1 & 17.7 & 25.7 & 8.6 & 19.2 & 42.9 & 91.0 & 43.8 & 16.3 & 93.0 & 27.2 & 7.2 \\
\hline \multicolumn{13}{|l|}{$\begin{array}{l}\text { Eastern Europe } \\
\text { Czech }\end{array}$} \\
\hline Republic & 12.3 & 14.0 & 17.8 & 9.1 & 18.6 & 48.6 & $\begin{array}{l}96.8 \\
100 .\end{array}$ & 28.0 & 6.8 & $\begin{array}{l}97.7 \\
100 .\end{array}$ & 6.5 & 1.8 \\
\hline Hungary & 0.6 & 8.5 & 12.5 & 1.9 & 7.4 & 40.7 & 0 & 59.0 & 4.0 & 0 & 29.6 & 1.7 \\
\hline Poland & 5.4 & 10.2 & 14.1 & 6.3 & 12.4 & 38.3 & 97.3 & 41.2 & 10.9 & 97.1 & 18.5 & 4.7 \\
\hline Romania & 5.7 & 12.8 & 21.0 & 5.8 & 12.3 & 44.6 & 96.5 & 27.2 & 3.5 & 94.3 & 11.3 & 1.6 \\
\hline Slovakia & 3.0 & 8.6 & 11.5 & 3.5 & 11.0 & 38.7 & 97.5 & 51.9 & 11.5 & 95.9 & 24.8 & 5.6 \\
\hline \multicolumn{13}{|l|}{ Southern Europe } \\
\hline Cyprus & 0.8 & 6.7 & 7.4 & 8.4 & 11.6 & 34.5 & 94.9 & 39.4 & 3.4 & 98.3 & 21.2 & 0.4 \\
\hline Greece & 1.7 & 9.2 & 15.8 & 8.3 & 11.1 & 41.8 & 98.7 & 52.7 & 13.5 & 98.2 & 34.0 & 6.0 \\
\hline Italy & 10.0 & 13.2 & 19.1 & 7.0 & 13.6 & 43.9 & 93.0 & 48.1 & 26.0 & 95.2 & 30.6 & 10.8 \\
\hline Portugal & 0.9 & 8.7 & 10.1 & 5.8 & 8.7 & 34.2 & 96.6 & 39.4 & 13.6 & 95.9 & 24.6 & 10.5 \\
\hline Slovenia & 1.5 & 17.8 & 20.7 & 11.3 & 14.9 & 47.8 & 96.3 & 55.4 & 24.4 & 92.7 & 28.7 & 7.6 \\
\hline Spain & 7.6 & 10.6 & 14.7 & 5.4 & 10.0 & 32.0 & 96.2 & 45.8 & 24.2 & 96.8 & 37.1 & 10.3 \\
\hline
\end{tabular}

Source: EU-LFS 2016, authors' elaboration

\section{Conclusions}

This chapter has provided an overview on living arrangements across 21 European countries based on recent data from the European Labor Force Surveys. We have not specifically addressed the background factors behind the observed patterns. Instead, we focused our attention on showing how (dis)similar living arrangements are across European countries and how they have changed since 2006. 
The variations in living arrangements among European countries are most evident for parental coresidence in young adulthood (20-29 years old), child coresidence in middle to old age (50-69), and lone living for women in the later life stages (80+). Spousal coresidence peaks at around 65-69 years old for men, at roughly 77 per cent, but peaks for women at ages 35-39 at around 75 per cent. Changes in living arrangements have taken place between the years 2006 and 2016. Young women in particular have delayed their departure from parental home. Spousal and child coresidence have dropped for both sexes, particularly in the peak childbearing years. People are slightly more likely to live alone in 2016 than in 2006. In late life, spousal coresidence has substantially increased, particularly for women, most likely due to increased longevity of their spouse, and living alone has in response modestly decreased. Living alone before age 60 remains to be uncommon in Europe, although more prevalent than other parts of the world (Esteve et al., forthcoming). Women are more likely than men to live alone across all life stages, particularly in old age, in most countries. As union instability and childlessness become commonplace, living alone in middle and late life stages will become increasingly common.

The regional pattern that emerges in most dimensions studied in this chapter conform to the traditional pattern that divides Europe into "strong" family systems, such as those found in the Mediterranean countries (Italy, Spain, Greece), and "weak" family systems, exemplified by central and northern European countries such as Germany and the United Kingdom (Reher, 1998; Schwanitz \& Mulder, 2015). Our findings show that the regional divide of living arrangements persists in Europe. Northern and Western Europe are characterized by earlier departure from parental home, earlier union formation, and higher level of lone living. Northern Europe particularly shows early childbearing and high levels of single motherhood. Eastern and Southern Europe are marked by later departure from the parental home, later union formation, and higher coresidence with children in later ages.

Behind these differences, scholars have emphasized different explanatory factors. Welfare regimes both compliment and reinforce how family members organize themselves by promoting individualism or familism through social care allowances and programs (Esping-Andersen, 1990, 1999). However, evidence also points to the fact that structural factors only partially explain the level of social exchanges families have with one another and normative climate continues to play a role (Jappens \& Van Bavel, 2012). The effect of social norms and culture therefore can be either bi-directional, or at least difficult to disentangle.

Labor market and other economic conditions drive both individual and family-level coping strategies, such as living together for the benefit of the economy of scale (Danziger \& Ratner, 2010). In line with research in the United States, European scholars found that the economic crisis of 2008 has delayed the transition of adulthood for individuals aged 18 to 34 (Lennartz et al., 2016). This may be manifested in the forms of the postponing the exit from one's parental home, delaying union formation (especially for men), and delaying or foregoing child-bearing (Pailhé \& Régnier-Loilier, 2015) which then shape the household structure in which one lives. This is reflected in our findings in the increase of parental coresidence and the decrease of spousal and child coresidence between 2006 and 2016 for individuals aged 20 to 29.

Mediterranean countries continue to show strong intra-familial solidarity in young adults' later departure from parental home, observed both from the young adults' perspective and from the middle-aged parents' perspective. Delay in marriage is clearly associated with a delay in young adults' timing of flying the nest in countries such as Italy (Giuliano, 2007). Alongside economic conditions and culture, housing availability and policies can heavily influence the living arrangements of individuals. For example, in Spain, the exceptionally high rate of homeownership (Cabré \& Módenes Cabrerizo, 2004) in combination with steadily rising rent in major cities across the country might discourage the younger generation from moving out of parental household, particularly during and immediately after the crisis (Blanco-Romero et al., 2018). Strong government control of public housing such as the case for the Netherlands (Smits et al. 2014) facilitates independent living, while relatively easy and flexible entry into home ownership in Sweden positively correlates with entry into marital union (Holland, 2012).

Moreover, the intensification of competition among specialized jobs led to the prolongation of education in the recent years (Psacharopoulos \& Patrinos, 2018) implied that young adults spent more years of their lives as dependents in their parents' household. The phenomenon, dubbed "emerging adulthood" (Tanner \& Arnett, 2016), specifically point to individuals aged 18 to 25 , whose emancipation may be delayed by further need to explore their identities and finding their place in the world.

Our results highlight the fact that cross-national variations in living arrangements in Europe tend to take place around the timing of men and women's transition to adulthood. Key events that occur during this time frame in an individual's life course include leaving parental home, forming conjugal partnership, and childbearing, all of which shape one's propensity to live with parents, partner, and/or child(ren). Multi-generational households remain uncommon in Europe, and as a result, union formation typically coincide with the departure from parental home. Higher union instability lead to single parenthood, mostly affecting women. In combination with fertility decline and union instability across Europe, coresidence with primary kin has become less common with time. The modest but 
stable increase in people living alone might be in part a response to social changes. Future research should explore the specific causes and implications for societies of changes in living arrangements. 


\section{References}

Alders, M. P. C., \& Manting, D. (2001). Household scenarios for the European Union, 1995-2025. Genus, 57(2), 17-47. JSTOR.

Billari, F. C., \& Liefbroer, A. C. (2010). Towards a new pattern of transition to adulthood? Advances in Life Course Research, 15(2-3), 59-75. https://doi.org/10.1016/j.alcr.2010.10.003

Billari, F. C., \& Wilson, C. (2001). Convergence towards diversity? Cohort dynamics in the transition to adulthood in contemporary Western Europe. MPIDR Working Paper 2001-039, 30.

Blanco-Romero, A., Blázquez-Salom, M., \& Cànoves, G. (2018). Barcelona, Housing Rent Bubble in a Tourist City. Social Responses and Local Policies. Sustainability, 10(6), 2043. https://doi.org/10.3390/su10062043

Buchmann, M. C., \& Kriesi, I. (2011). Transition to Adulthood in Europe. Annual Review of Sociology, 37(1), 481503. https://doi.org/10.1146/annurev-soc-081309-150212

Burgess, E. (1916). The function of socialization in social evolution. The University of Chicago press.

Cabré, A., \& Módenes Cabrerizo, J. A. (2004). Home ownership and social inequality in Spain. In Home Ownership and Social Inequality In a Comparative Perspective (pp. 233-254). Stanford University Press.

Danziger, S., \& Ratner, D. (2010). Labor Market Outcomes and the Transition to Adulthood. The Future of Children, 20(1), 133-158. JSTOR.

Esping-Andersen, G. (1990). The Three Worlds of Welfare Capitalism. Princeton University Press.

Esping-Andersen, G. (1999). Social Foundations of Postindustrial Economies. OUP Oxford.

Esteve, A., García-Román, J., \& Lesthaeghe, R. (2012). The family context of cohabitation and single motherhood in Latin America. Population and Development Review, 38(4), 707-727.

Esteve, A., \& Liu, C. (2018). Family and household composition in Asia. In Routledge Handbook of Asian Demography (1st ed., pp. 370-393). Routledge.

Esteve, A., Reher, D. S., Treviño, R., Zueras, P., \& Turu, A. (forthcoming). Cross-national variations in living alone over the life-course: Comparative perspectives on an emerging issue. Population and Development Review, Forthcoming.

Eurostat. (2006). Population statistics. https://ec.europa.eu/eurostat/documents/3217494/5685052/KS-EH-06-001EN.PDF/1e141477-9235-44bb-a24b-a55454c2bc42?version=1.0

Eurostat. (2015). People in the EU: Who are we and how do we live? : 2015 edition. Publications Office. http://bookshop.europa.eu/uri?target=EUB:NOTICE:KS0415567:EN:HTML

Eurostat. (2019). Mean age at first marriage by sex.

https://ec.europa.eu/eurostat/databrowser/view/tps00014/default/table?lang=en

Fokkema, T., \& Liefbroer, A. C. (2008). Trends in living arrangements in Europe: Convergence or divergence? Demographic Research, 19, 1351-1418. https://doi.org/10.4054/DemRes.2008.19.36

Giuliano, P. (2007). Living Arrangements in Western Europe: Does Cultural Origin Matter? Journal of the European Economic Association, 5(5), 927-952. https://doi.org/10.1162/JEEA.2007.5.5.927

Goldscheider, F. K., \& DaVanzo, J. (1985). Living arrangements and the transition to adulthood. Demography, 22(4), 545-563. https://doi.org/10.2307/2061587 
Hajnal, J. (1965). European Marriage Patterns in Perspective. In D. V. Glass \& D. E. C. Eversley (Eds.), Population in History. Essays in Historical Demography. Volume I: General and Great Britain. (pp. 101-143). Aldine Transaction.

Hajnal, J. (1982). Two Kinds of Preindustrial Household Formation System. Population and Development Review, 8(3), 449-494. JSTOR. https://doi.org/10.2307/1972376

Hareven, T. K. (1993). Family Time \& Industrial Time: The Relationship Between the Family and Work in a New England Industrial Community. University Press of America.

Holland, J. A. (2012). Home and Where the Heart Is: Marriage Timing and Joint Home Purchase. European Journal of Population / Revue Européenne de Démographie, 28(1), 65-89. https://doi.org/10.1007/s10680-011-9242-1

Jappens, M., \& Van Bavel, J. (2012). Regional family norms and child care by grandparents in Europe. Demographic Research, 27, 85-120. JSTOR.

Laslett, P., \& Wall, R. (1972, November). Household and Family in Past Times by Peter Laslett. Cambridge Core. https://doi.org/10.1017/CBO9780511561207

le Play, F. (1871). L’Organisation de la famille. Kessinger Publishing.

Lennartz, C., Arundel, R., \& Ronald, R. (2016). Younger Adults and Homeownership in Europe Through the Global Financial Crisis. Population, Space and Place, 22(8), 823-835. https://doi.org/10.1002/psp.1961

Miettinen, A., Rotkirch, A., Szalma, I., Donno, A., \& Tanturri, M.-L. (2015). Increasing childlessness in Europe: Time trends and country differences. Families and Societies Working Paper Series, 33.

Ogburn. (1933). The family and its functions. Recent social trends in the United States (Vol. 1). New York: McGraw-Hill.

Pailhé, A., \& Régnier-Loilier, A. (2015). Unemployment delays parenthood in France. Population \& Societies, 528, $1-4$.

Parsons, T. (1949). The social structure of the family. In R. N. Anshen (Ed.), The family: Its function and destiny.

Psacharopoulos, G., \& Patrinos, H. A. (2018). Returns to Investment in Education: A Decennial Review of the Global Literature. The World Bank. https://doi.org/10.1596/1813-9450-8402

Reher, D. S. (1998). Family Ties in Western Europe: Persistent Contrasts. Population and Development Review, 24(2), 203-234. JSTOR. https://doi.org/10.2307/2807972

Schwanitz, K., \& Mulder, C. H. (2015). Living Arrangements of Young Adults in Europe. Comparative Population Studies, 40(4). http://www.comparativepopulationstudies.de/index.php/CPoS/article/view/158

Tanner, J. L., \& Arnett, J. J. (2016). The emergence of emerging adulthood: The new life stage between adolescence and young adulthood. In A. Furlong (Ed.), Routledge Handbook of Youth and Young Adulthood.

https://doi.org/10.4324/9781315753058-13

Thornton, A. (2013). Reading History Sideways: The Fallacy and Enduring Impact of the Developmental Paradigm on Family Life. University of Chicago Press.

United Nations. (2018). United Nations demographic yearbook 2017. 